\title{
Feed training of juvenile giant trahira under different light intensities
}

\author{
Ana Lúcia Salaro ${ }^{1}$, Mateus Moraes Tavares ${ }^{1}$, William Chaves ${ }^{1}$, Daniel Abreu Vasconcelos \\ Campelo $^{1}$, Jener Alexandre Sampaio Zuanon ${ }^{1}$, Ronald Kennedy Luz $^{2}$
}

\footnotetext{
1 Universidade Federal de Viçosa, Departamento de Biologia Animal, Av. P.H. Rolfs s/n, Centro, 36570-000, Viçosa, Minas Gerais.

${ }^{2}$ Laboratório de Aquacultura da Universidade Federal de Minas Gerais-UFMG, Av. Antônio Carlos, 6627, 31270-901, Belo Horizonte, Minas Gerais, Brasil.
}

ABSTRACT - The aim of this study was to evaluate the influence of light intensity on the feed training of juvenile giant trahiras (Hoplias lacerdae). A completely randomized design with four light treatments and three replicates was used, and the following light intensities were tested: 204.9; 177.58; 54.64 and 0.00 lux. Juvenile giant trahiras (length $=3.0 \pm 0.4 \mathrm{~cm}$ and weight $=0.5 \pm 0.05 \mathrm{~g})$ were stocked at $6 \mathrm{fish} \mathrm{L}^{-1}$ in 12 rectangular tanks $(24 \times 20 \times 14 \mathrm{~cm})$ containing six liters of water, and subjected to feed training to accept dry diets. At the end of the experiment (21 days), weight gain, length gain, survival, cannibalism, and mortality rates were evaluated. Data were subjected to regression analysis at 5\% probability. Different light intensities did not affect growth, survival, mortality, or cannibalism rates in juvenile giant trahiras during the feed training. Therefore, this species can be trained to accept dry diets in the presence or absence of light.

Key Words: cannibalism, carnivorous fish, feed training, Hoplias lacerdae, light

\section{Introduction}

Carnivorous fish have recently gained popularity in the aquaculture, mainly due to the excellent quality of their meat, the growth performance of cultivated species and attractive market prices. However, commercial farming of carnivorous species requires special care, due to high rates of cannibalism, which can cause high yield losses (Luz et al., 2000), as well as the need to feed training the fish to accept inert diets (Kubitza \& Lovshin, 1997; Luz et al., 2002; Soares et al., 2007; Feiden et al., 2008).

However, research on feed training has been mostly confined to test diets, and has not taken into account environmental factors, which may induce cannibalism among carnivorous fish species.

Light intensity is a particularly important environmental variable, and can influence pigmentation, physiological responses to stress, changes in biorhythm and food intake (Puvanendran \& Brown, 2002). Besides, light intensity affects locomotor activity and increasing intensities can accelerate consumption of metabolic reserves (Downing \& Litvak, 2002). Furthermore, luminosity changes can influence the regulation of melatonin, somatotropin and thyroid hormones (Boeuf \& Le Bail, 1999), which act on the hypothalamus and interfere with fish growth and survival (Zhdanova \& Reebs, 2006). The ideal light intensity range varies from species to species, and can determine the developmental potential of the animal (Boeuf \& Le Bail, 1999), probably because it affects the location and capture of prey.

Among neotropical carnivorous fish species with the potential for captive breeding, the giant trahira (H. lacerdae) stands out as a species that, after feed training, presents good survival and growth rates when fed exclusively with commercial feed (Luz et al., 2001; Salaro et al., 2003; Nogueira et al., 2005; Salaro et al., 2006; Salaro et al., 2008).

The objective of the present study was to evaluate the influence of light intensity on the feed training of juvenile giant trahira.

\section{Material and Methods}

Experiments were conducted at the Laboratório de Nutrição de Peixes of Setor de Piscicultura do Departamento de Biologia Animal (Laboratory of Fish Nutrition at the Aquaculture Section of the Animal Biology Departament), Universidade Federal de Viçosa, Brazil, over a period of 21 days.

A completely randomized design with four treatments (consisting of different light intensities) and three replications was used. Specific light intensities tested were obtained by applying different types of covers over the tanks, which are generally used in rearing fish, thus resulting in light intensity values that are not equidistant. The light 
intensity values tested (in lux) were: 204.9; 177.58; 54.64 and 0.00. Light intensities were obtained as follows: for 204.9 lx, no coverage was applied; for 177.58 lx, tanks were covered with black plastic over $1 / 3$ of their surface area; for $54.64 \mathrm{~lx}$, tanks were covered with shade screen (75\% coverage); for $0.00 \mathrm{~lx}$, tanks were fully covered with black plastic. Resulting light intensities were measured using photometer/radiometer (Li-185, LI-COR, Lincoln, NE, EUA). To prevent fish from jumping out, tanks were covered with an 11.0-mm diameter plastic screen.

Tanks used for the different light treatments were housed in the Laboratório de Nutrição de Peixes, where lighting was applied by means of fluorescent lamps. Lamps were turned on from $7 \mathrm{~h}$ to $19 \mathrm{~h}$, resulting in a 12-hour photoperiod.

Juvenile giant trahiras (standard length of $3.0 \pm 0.4 \mathrm{~cm}$ and weight of $0.5 \mathrm{~g} \pm 0.05 \mathrm{~g}$ ) were stocked ( 6 animals $\mathrm{L}^{-1}$ ) in 12 rectangular, blue-colored, translucent, tanks $(24 \times 20$ $\times 14 \mathrm{~cm}$; $6 \mathrm{~L}$ capacity), which were laterally coated with black plastic to avoid unwanted light.

Tank water temperature was kept constant $\left(26.0 \pm 0.5^{\circ} \mathrm{C}\right)$ with the aid of electric heaters (10 watts) and a thermostat. Oxygenation of the water was supplied by air pumps and an airstone, and was maintained at approximately $6 \mathrm{mg} \mathrm{L}^{-1}$. The water $\mathrm{pH}$ was maintained at 6.9. Water was maintained at $4 \mathrm{~g} \mathrm{~L}^{-1}$ salinity throughout the experimental period.

Feed training was conducted using food pellets following methods proposed by Luz et al. (2002), with modifications to the time of transition diets (Kasai et al., 2011) (Tables 1 and 2).

Feeding was initiated at 8:00, 12:00 and 16:00. Three minutes before each feeding, tanks were completely uncovered to enable observation of the following behavioral aspects: animal positions, group formations, acceptance of the diets (intake and/or rejection), and competition for the food pellets. During the feeding period, the occurrence of fish death (fish found dead with no signs of injuries on the body or fins) and cannibalism (dead or alive fish with signs of injuries on the body or fins; or fish which had disappeared) was recorded. All animals in these conditions were quantified and removed from the tanks.

Table 1 - Percentage of the mixture (bovine heart and ration) and number of days of supply of test diets used in the feed training of juvenile giant trahira (Hoplias lacerdae)

\begin{tabular}{cccc}
\hline Diet & Composition & Days \\
\hline 1 & $80 \%$ bovine heart $+20 \%$ commercial ration & 5 \\
2 & $60 \%$ bovine heart $+40 \%$ commercial ration & 4 \\
3 & $40 \%$ bovine heart $+60 \%$ commercial ration & 4 \\
4 & $20 \%$ bovine heart $+80 \%$ commercial ration & 4 \\
5 & $100 \%$ commercial ration & 4 \\
\hline
\end{tabular}

Table 2 - Chemical composition of basal diet and bovine heart

\begin{tabular}{lcc}
\hline & Bovine heart ${ }^{1}$ & $\begin{array}{c}\text { Commercial } \\
\text { ration }^{2}\end{array}$ \\
\hline Crude protein (g/100 g of sample) & 81.37 & 42.00 \\
Crude lipid (g/100 g of sample) & 9.15 & 7.00 \\
Crude fiber (g/100 g of sample) & 2.08 & 5.00 \\
Moisture (g/100 g of sample) & 28.27 & 8.00 \\
Ash (g/100 g of sample) & 7.19 & 15.00 \\
Calcium (g/100 g of sample) & 0.19 & 4,00 \\
Phosphorus (g/100 g of sample) & 1.11 & 1.50 \\
Gross energy (kcal/kg of sample) & 5051.98 & -3 \\
\hline
\end{tabular}

${ }^{1}$ Composition based on dry matter percentage (AOAC, 1984).

2 Manufacturer's data.

${ }^{3}$ Data not supplied by the manufacturer.

The commercial ration, with levels of security described by the manufacturer, was enriched with (product/kg diet): folic acid - $6.00 \mathrm{mg}$; pantothenic acid $75.00 \mathrm{mg}$; antioxidant - $185.00 \mathrm{mg}$; choline - 1,000.00 mg; copper - $6.00 \mathrm{mg}$ cobalt - $0.30 \mathrm{mg}$; iron - $75.00 \mathrm{mg}$; inositol - $12.00 \mathrm{mg}$; iodine - $2.00 \mathrm{mg}$; manganês $30.00 \mathrm{mg}$; selenium - $0.16 \mathrm{mg}$; vit. A - 18,000 IU; vit. B1 - $15.00 \mathrm{mg}$; vit. B12 $0.06 \mathrm{mcg}$; vit. B2 - $30.00 \mathrm{mg}$; vit. B6 - $15.00 \mathrm{mg}$; vit. C - $300.00 \mathrm{mg}$; vit. D3 3,000 IU; vit. E - $75.00 \mathrm{mg}$; vit. K3 - $7.50 \mathrm{mg}$; zinc - $90.00 \mathrm{mg}$; niacin - $150.00 \mathrm{mg}$

At the end of the day (at $17 \mathrm{~h}$ ), water volume was completely renewed in all tanks. During this procedure, the fish were caught by hand net and immediately transferred to another tank under the same experimental conditions.

At the end of feed training (21 days), all fish were counted to determine cannibalism, survival and mortality rates. Fish were then weighed on a precision scale (model Toledo MB $45^{\circledR}+/-0.001 \mathrm{~g}$ ) and measured using a digital caliper (model Coolant Proof Absolute series $500^{\circledR}+/-0.001 \mathrm{~m}$ ) to calculate weight and length gains.

Data were subjected to regression analysis at 5\% probability using the software SAEG. To choose the appropriate regression model, it was considered the significance of regression coefficients, test results, magnitudes of the coefficients of determination as well as the behavior variables in thus study.

\section{Results and Discussion}

From the first day of the experiment, it was noted immediate acceptance of the food diets by the fish, regardless of light intensity. In the final stages of the experiment, the fish were seizing the food even before the pellets reached the bottom of tanks. Rejection was not observed at any stage of the feed training, even with changes in the diets, confirming that light intensity does not affect feed training in this fish species. According to Salaro et al. (2006), this effect may be due to the fact that giant trahiras (H. lacerdae) also use smell for the detection of food.

Agonistic interactions, such as dominance and competition for food, were not frequently observed among fish in different light conditions. Generally, disputes 
occurred at the beginning of each feeding, and lasted until each animal had consumed at least one pellet of food. After this initial period, disputes became less frequent or were not observed.

With respect to the position of fish in the tank and the formation of groups, animals under $177.58 \mathrm{~lx}$ remained clustered in the portion of the tank covered by black plastic (1/3 of the tank), even after removal of the screens for feeding. In contrast, fish subjected to 204.9, 54.64 and $0.00 \mathrm{~lx}$ were scattered all over the tank. This clustering observed for the 177.58 lx group may be related to the preference of these animals to be constantly covered. In the larval stage, there is a distribution preference in response to optimal environmental light conditions for this species (Nass \& Iglesias, 1996). Furthermore, giant trahira are crepuscular fish (Bussing, 1987), which prefer low-lit areas. Therefore, fish subjected to $177.58 \mathrm{~lx}$ in this experiment attempted to group together under the shaded area of the tank. In other treatments, the light intensity inside the tank was applied homogeneously, resulting in a random distribution across the entire length of the tank.

The light intensities tested did not affect the average gains in weight and length observed during feed training. Similarly, cannibalism, mortality and survival rates were unaffected by light intensities (Table 3). These results are in agreement with previous studies, where light intensity did not affect the performance of juvenile Perca fluviatilis (Strand et al., 2007), Hoplias lacerade fingerlings (Salaro et al., 2006), and post-larval Dicentrachus labrax (Cuvier-Péres et al., 2001). In contrast, Han et al. (2005) reported significant differences in weight gain for juvenile Leiocassis longirostris, and observed that fish reared under intermediate intensity light yielded higher productive performance. Similarly, Trippel et al.(2003), in a study of juvenile Melanogrammus aeglefinus, observed that application of continuous, low-intensity light promoted weight gain in these animals. Therefore, based on the above, the effect of light intensity changes from species to species.

Table 3 - Mean values of weight gain, gain in length, cannibalism, mortality and survival rates of juvenile Hoplias lacerdae after feed training (21 days) under different light intensities

\begin{tabular}{lccccr}
\hline Variable & \multicolumn{5}{c}{ Light intensities (lx) } \\
\cline { 2 - 6 } & 204.9 & 177.58 & 54.64 & 0.00 & CV (\%) \\
\hline${\text { Weight gain }(\mathrm{g})^{1}}$ & 0.26 & 0.28 & 0.28 & 0.20 & 16.09 \\
Length gain (cm) $^{1}$ & 0.21 & 0.21 & 0.23 & 0.19 & 30.78 \\
Cannibalism rate (\%) $^{1}$ & 16.67 & 7.41 & 9.26 & 5.56 & 73.09 \\
Mortality rate (\%) $^{1}$ & 5.56 & 22.22 & 40.74 & 9.26 & 162.00 \\
Survival rate $(\%)^{1}$ & 77.78 & 70.37 & 50.00 & 85.19 & 30.72 \\
\hline${ }^{1}$ Not significant $(\mathrm{P}>0.05)$. & & & & &
\end{tabular}

The best performance by juvenile Melanogrammus aeglefinus was reported under continuous low light conditions (constant illumination) versus animals reared under high-intensity light or a natural photoperiod. These results may be related to the swimming activity of these fish, since those in lower light conditions displayed reduced swimming activity, expending less energy (Trippel et al., 2003). The giant trahira species studied in the present experiment has a preference for standing water, such as lakes or reservoirs (Oyakawa \& Mattox, 2009). Thus, their swimming activity is generally low, as observed in this experiment: most of the time the fish remained immobile on the bottom of the tank, and only moved during feeding periods.

It is possible that the lack of significant differences in cannibalism rate observed with increasing luminous intensity is related to the fact that all intensities tested were appropriate for the location and capture of food. This fact, along with the feeding frequency used, may have contributed to the development of a state of satiation in the animals; therefore inhibiting cannibalism. In support of this theory, cannibalistic behavior is inversely proportional to food availability (Hecht \& Appelbaum, 1988).

The high survival rates observed in this experiment confirm that the feed training methodology used was efficient. These high survival rates may be due to the fact that the used of homogeneous lots of fish and provided an adequate diet to meet the nutritional requirements of the species, along with good water quality: the main factors responsible for the success of feed training carnivorous fish (Luz et al. 2000; Hecht \& Appelbaum, 1988). However, additional studies on the influence of environmental conditions on giant trahira farming must be conducted to determine the effects of these variables on the physiology and welfare of the animal, with the aim of increasing the productivity of this species.

\section{Conclusions}

All light intensities tested are suitable for feed training juvenile giant trahira (Hoplias lacerdae), and do not affect weight gain, length gain, or cannibalism or mortality rates.

\section{Acknowledgments}

The authors thank the Conselho Nacional de Desenvolvimento Cientifico e Tecnológico (CNPq), for the scholarship granted to the following undergraduate research students: Mateus Moraes Tavares and William Chaves. 


\section{References}

ASSOCIATION OF OFFICIAL ANALYTICAL CHEMISTS - AOAC. Official methods of analysis. 14.ed. Washington, 1984. 1141p.

BOEUF, G.; LE BAIL, P. Does light have an influence on fish growth? Aquaculture, v.177, n.4, p.129-152, 1999.

BUSSING, W.A. Peces de las aguas continentales de Costa Rica. San Jose: Editorial de la Universidadde Costa Rica, 1987. 271p.

CUVIER-PÉRES, A.; JOURDAN, S.; FONTAINE, P. et al. Effects of light intensity on animal husbandry and digestive enzyme activities in sea bass Dicentrachus labrax post-larvae. Aquaculture, v.202, n.3-4, p.317-328, 2001.

DOWNING, G.; LITVAK, M.K. Effects of light intensity, spectral composition and photoperiod on development and hatching of haddock (Melanogrammus aeglefinus) embryos. Aquaculture, v.213, n.1-4, p.265-278, 2002.

FEIDEN, A.; FERRARI, E.; BOSCOLO, W.R. et al. Desempenho e sobrevivência de alevinos de Black bass (Micropterus salmoides, Lacepède 1802), submetidos ao condicionamento alimentar, utilizando diferentes patês protéicos. Ciências Agrárias, v.29, p.449-458, 2008.

HAN, D.; XIE, S.; LEI, W. et al. Effect of light intensity on growth, survival and skin color of juvenile Chinese longsnout catfish (Leiocassis longirostris Gunther). Aquaculture, v.248, n.1-4, p.299-306, 2005.

HECHT, T.; APPELBAUM, S. Observations on intraspecific aggression and coeval sibling cannibalism by larva and juvenile Clarias gariepinus (Clariidae: Pisces) under controlled conditions. Journal of Zoology, v.22, n.14, p.21-44, 1988.

KASAI, R.Y.D.; SALARO, A.L.; ZUANON, J.A.S. et al. Training of trairão fingerlings fed with diets containing different levels of vitamin C. Revista Brasileira de Zootecnia, v.40, n.3, p.463-468, 2011.

KUBITZA, F.; LOVSHIN, L.L. The use of freeze-dried krill to feed train largemouth bass (Micropterus salmoides): feeds and training strategies. Aquaculture, v.148, p.299-312, 1997.

LUZ, R.K.; SALARO, A.L.; SOUTO, E.F. et al. Desenvolvimento de alevinos de trairão com dietas artificiais em tanques de cultivo. Revista Brasileira de Zootecnia, v.30, p.1159-1163, 2001.

LUZ, R.K.; SALARO, A.L.; SOUTO, E.F. et al. Avaliação de canibalismo e comportamento territorial de alevinos de trairão
(Hoplias lacerdae). Acta Scientiarum, v.22, n.2, p.465-469, 2000.

LUZ, R.K.; SALARO, A.L.; SOUTO, E.F. et al. Condicionamento alimentar de alevinos de trairão (Hoplias cf. lacerdae). Revista Brasileira de Zootecnia, v.31, n.5, p.1881-1885, 2002.

NASS, K.; IGLESIAS, J. Illumination in first feeding tanks for marine fish larvae. Aquaculture, v.15, n.4, p.291-300, 1996.

NOGUEIRA, G.C.C.B.; SALARO, A.L.; LUZ, R.K. et al. Desempenho produtivo de juvenis de trairão (Hoplias lacerdae) alimentados com rações comerciais. Revista Ceres, v.52, n.302, p.401-497, 2005.

OYAKAWA, O.T.; MATTOX, G.M.T. Revision of the Neotropical trahiras of the Hoplias lacerdae species-group (Ostariophysi: Characiformes: Erythrinidae) with descriptions of two new species. Neotropical Ichthyology, v.7, n.2, p.117-140, 2009.

PUVANENDRAN, V.; BROWN, J.A. Foraging, growth and survival of Atlantic cod larvae reared in different light intensities and photoperiods. Aquaculture, v.214, n.1-4, p.131-151, 2002.

SALARO, A.L.; LUZ, R.K.; NOGUEIRA, G.C.C. et al. Diferentes densidades de estocagem na produção de alevinos de trairão (Hoplias cf. lacerdae). Revista Brasileira de Zootecnia, v.32, n.5, p.1033-1036, 2003.

SALARO, A.L.; LUZ, R.K.; ZUANON, J.A.S. et al. Desenvolvimento de alevinos de trairão (Hoplias lacerdae) na ausência de luz. Acta Scientiarum, v.28, n.1, p.47-50, 2006.

SALARO, A.L.; LUZ, R.K.; SAKABE, R. et al. Níveis de arraçoamento para juvenis de trairão (Hoplias lacerdae). Revista Brasileira de Zootecnia, v.37, p.967-970, 2008.

SOARES, E.C.; PEREIRA-FILHO, M.; ROUBACH, R. et al. Condicionamento alimentar no desempenho zootécnico do tucunaré. Revista Brasileira de Engenharia de Pesca, v.2, p.35-48, 2007.

STRAND, Å.; ALANARA, A.; STAFFAN, F. et al. Effects of tank colour and light intensity on feed intake, growth rate and energy expenditure of juvenile Eurasian perch, Perca fluviatilis L. Aquaculture, v.272, p.312-318, 2007.

TRIPPEL, E.A.; NEIL, S.R.E. Effects of photoperiod and light intensity on growth and activity of juvenile haddock (Melanogrammus aeglefinus). Aquaculture, v.217, p.633-645, 2003.

ZHDANOVA, I.V.; REEBS, S.G. Circadian rhythms in fish. In: SLOMAN, K.A.; WILSON, R.W.; BALSHINE, S. (Orgs.) Behaviour and physiology of fish. San Diego: Academic Press, 2006. p.197-228. 